\title{
Efficacy of Watercress on Alleviating the Side Effects of Re-used Oil on the Fertility of Adult Male Rats
}

\author{
Mohamed H. Haggag, Naeem M. Rabeh
}

M. S. Ziada, Fatema El-Zahraa M. Husien

\begin{abstract}
The present study was aimed to study the effect of watercress supplementation at three different levels for 8 weeks on alleviating the side effects of reused oil on sex hormones of adult male rats. Thirty male albino rats were divided into 5 groups; group (1) was fed on basal diet (as a control negative group). Group (2) was fed on basal diet containing $4 \%$ of re-used oil substituted with oil content of the basal diet (as a control positive group). Groups (3, 4 and 5) as the same of group (2) and supplemented with 5, 7.5 and $10 \%$ dried watercress respectively.
\end{abstract}

Key words: Watercress powder, reused oil, fertility, reproductive performance.

\section{Introduction}

Infertility affects $15 \%$ of all couples. About $39 \%$ of these couples, the male generates semen analyzed as abnormal. Spermatogenic failure, including a zoospermia and oligospermia, is one of the important causes of male infertility (Park et al., 2007).

The hidden factor has been oxidative stress (OS) which is now recognized as an important and probable cause of idiopathic male infertility (Agarwal et al., 2014). The fact that sperm contains a large amount of unsaturated fatty acid makes it prone to oxidation. Spermatogenic cells

Egyptian Journal for Specialized Studies - Vol (8) N (25) January 2020（ 5 ) 
with oxidatively damaged DNA undergo apoptotic elimination through p53-dependent and independent mechanism which can lead to infertility. Likewise, recent data has shown that disorders such as poor fertilization, pregnancy loss, birth defects, poor embryonic development and even childhood cancer are correlated with high susceptibility of spermatozoa to oxidative insult (Fujii and Imai, 2014 and Azantee and Lokman, 2015).

During the frying process, cooking oil is exposed to an extremely high temperature in the presence of air and moisture. Under such conditions, a complex series of chemical reactions takes place, resulting in loss of both quality and nutritional values of the cooking oil. Repeatedly heating the cooking oils initiates a series of chemical reactions, modifying the fat constituents of cooking oil through oxidation, hydrolysis, polymerization, and isomerization, eventually resulting in lipid peroxidation (Choe and Min, 2007).

Lipid peroxidation generates a wide spectrum of volatile or non-volatile components, including free fatty acids, alcohols, aldehydes, ketones, hydrocarbons, trans isomers, cyclic and epoxy compounds (Zhang et al., 2012 and Kaviyani et al., 2014).

As a result, when the same cooking oil is reused excessively, the chemical reactions enhance foaming, darkening of oil color, increased viscosity, and off-flavor. Hence, repeated heating of the oil can lead to degradation of the cooking oil, both chemically and physically. Exposure to oxygen at high temperatures leads to oxidation of triacylglycerides, which generates hydroperoxides. 
Hydroperoxides are unstable intermediates and rapidly break down into reactive free radicals to initiate autoxidation. The extreme heat during frying is the main initiator for autoxidation, in addition to other factors such as photonic agents, ionizing radiation, free radicals and chemical impacts (Leong et al., 2015).

Watercress (Nasturtium officinalis), is a member of the Brassicaceae family, originated in central and Western Europe but nowadays is spread all over the world (Biddington and Ling, 1983). It grows in different areas of Iran. This grass is long lasting with up-going stems that are quadrant and leaves that are periodic and feather like (Jafari and Hassandokht., 2012). Watercress is full of several protecting vitamins and can be used in the treatment of metabolic and chronic diseases. At the end of 19th century, it was used for blood filtration and also pulmonary diseases (Shahrokhi et al., 2009). Also, the use of watercress has been reported to prevent cellular damage and elevate the level of antioxidant in the body (Shahrokhi et al., 2009; Goda et al., 1999). Watercress is used in traditional medicine such as expectorant, appetizing and diuretic (Gill et al., 2007). Therefore, the present study was aimed to study the effect of watercress supplementation at three different levels for 8 weeks on alleviating the side effects of reused oil on sex hormones of adult male rats. 


\section{Materials and Methods}

\section{Materials:}

Fresh watercress was obtained from local market. Watercress was dried by the solar energy at $40^{\circ} \mathrm{c}$ for two days then grinded to get the powder at the National Research Center, Giza, Egypt. Reused oil was prepared by reheating the oil 15 times; $50 \mathrm{~g}$ potato pieces were fried at $180{ }^{\circ} \mathrm{C}$ with 3 minutes in every frying interval. Fresh sunflower oil was used as reference oil, according to the method of (Abdullah et al., 2012).

Rats: Adult male albino rats (Sprague- Dawley strain) ( $\mathrm{n}=30$ rat) weighing approximately $(150 \pm 5 \mathrm{~g}$.) was purchased from Helwan Experimental Animals Station.

Chemicals: Casein, vitamins, minerals and cellulose were purchased from El-Gomhoria Pharmaceutical Company - Cairo - Egypt.

\section{Methods:}

\section{A.Biological study:-}

Thirty adult male rats were housed in well aerated cages under hygienic conditions and fed on basal diet for one week for adaptation. All diets were formulated to cover the nutrient requirements of rats following the recommendations of the American Institute of Nutrition (AIN-93M) (Reeves et al., 1993). After this week rats was divided into 5 groups (6 rats each) as follow:- group (1) was fed on basal diet (as a control negative group).Group (2) was fed on basal diet containing $4 \%$ of re-used oil substituted with basal diet oil content (as a control positive group).Groups (3,4 and 5) as the same of group (2) 
supplemented with 5, 7.5 and $10 \%$ dried watercress respectively.

All rats were observed each day. Their feed intake (FI) was determined daily and body weights were obtained. Feed Efficiency Ratio (FER) was calculated. At the end of the experimental period ( 8 weeks), rats were fasted overnight before sacrificing and the blood samples were collected from each rat and was centrifuged to obtain serum.

\section{B. Bio chemical analysis:}

Serum sex hormons such as analysis such asfollicle stimulating hormone (FSH), luteinizing hormone (LH) and testosterone were determined according to (Haesslein and Lamb, 1976 and Collins et al., 1981). Serum Malondialdehyde (MDA) was determined according to (Satoh and Clinica, 1978). However, serum Catalase (CAT) was determined according to (Aebi, 1984 and Fossati, et al., 1982).Liver enzymes such as Aspartate aminotransferase (AST), alanine aminotransferase was according to (ALT) and alkaline phosphatase (ALP) were determined according to (Thomas, 1998; Young, 2000).Lipid profile such as Total cholesterol (TC), Triglycerides (TG), high density lipoprotein cholesterol (HDL-c) according to (Shih et al., 2000); low density lipoprotein cholesterol (LDL-c) and very low density lipoprotein (VLDL-c)were calculated as the equation of (Friadwald et al., 1972).

\section{C.Statistical analysis:}

The obtained results were analyzed according to SPSS program. ANOVA test was used to compare results 
among groups and $\mathrm{P}<0.05$ was considered to be significant (SPSS, 1986).

\section{Results and discussion:}

Table (1) illustrate the effect of reused oil and watercress on feed intake, body weight gain percent $(\mathrm{BWG} \%)$ and feed efficiency ratio of male albino rats. Regarding to mean values of feed intake, both control groups were 12.9 and $12.7 \mathrm{~g} / \mathrm{d}$, respectively. The highest mean value in tested groups was recorded at group that received $7.5 \%$ dried watercress followed by the group fed on $10 \%$.

Body weight gain $\%$ of + ve control positive group was non-significantly decreased compared with - ve control negative group with mean values $31.18 \pm 2.36$ and $34.87 \pm 2.34 \%$, respectively. There was no changes in $\mathrm{BWG} \%$ at the group that fed on $5 \%$ watercress, while supplementation with watercress at the level of 7.5 and $10 \%$ significantly increased $(\mathrm{P}<0.05) \mathrm{BWG} \%$ as compared with the + ve control positive group.

As regards to FER, non-significantly decreased in +ve control positive group compared with -ve control negative group. Moreover, there was no significant difference in FER among the groups treated with watercress at the level of 5 and $7.5 \%$ as compare to the both control groups. On the other hand, $10 \%$ watercress supplementation caused a significant increase in FER as compared to control groups. 
Table (1): Effect of reused oil and watercress on BWG\%, FI and FER of adult male rats

\begin{tabular}{|l|c|c|c|}
\hline Groups Parameters & $\begin{array}{c}\text { FI } \\
\text { (g/d/rat) }\end{array}$ & $\begin{array}{c}\text { BWG } \\
\text { \% }\end{array}$ & FER \\
\hline G1: Control (-ve) & 12.9 & $34.87 \pm 2.34^{\text {bc }}$ & $0.064 \pm 0.004^{\mathrm{b}}$ \\
\hline G2: Control (+ve) & 12.7 & $31.18 \pm 2.36^{\mathrm{c}}$ & $0.057 \pm 0.003^{\mathrm{b}}$ \\
\hline G3: Watercress 5\% & 13.8 & $34.64 \pm 3.07^{\mathrm{bc}}$ & $0.061 \pm 0.005^{\mathrm{b}}$ \\
\hline G4: Watercress 7.5\% & 16.8 & $41.24 \pm 0.96^{\mathrm{b}}$ & $0.059 \pm 0.001^{\mathrm{b}}$ \\
\hline G5: Watercress 10\% & 15.5 & $49.77 \pm 2.10^{\mathrm{a}}$ & $0.076 \pm 0.002^{\mathrm{a}}$ \\
\hline
\end{tabular}

Results are expressed as mean \pm SE.

Values in each column which have different letters are significantly different at $(\mathrm{P}<0.05)$.

The addition of dried watercress leaves in diet of Nile tilapia led to improve all growth performance, feed utilization parameters compared by the control group (Khalil, et al., 2015), these results are with the line with the obtained results in which watercress supplementation at $10 \%$ significantly increased $\mathrm{BWG} \%$ and FER as compared to the negative control group.

Table (2) illustrates the effect of reused oil and dried watercress on serum FSH, LH and testosterone hormones of male rats. The mean values of FSH were non-significantly decreased in + ve control positive group compared with -ve control negative group. There were non-significant changes in the mean value of serum FSH among all treated rats, as compared to both control groups.

The mean values of the luteinizing hormone $(\mathrm{LH})$ of - ve control group and + ve control positive group were 0.30 \pm 0.058 and $0.16 \pm 0.023 \mathrm{IU} / \mathrm{L}$, respectively with nonsignificant difference. While treated groups had $\mathrm{LH}$ values ranged between $0.30 \pm 0.058$ and $0.38 \pm 0.044 \mathrm{IU} / \mathrm{L}$ with 
non-significant changes. Rats fed on basal diet and supplemented with 7.5 or $10 \%$ watercress had significant increase $(\mathrm{P}<0.05)$ of $\mathrm{LH}$ hormone as compared to positive control group. The $-\mathrm{ve}$ control negative group had significant increase $(\mathrm{P}<0.05)$ in the mean value of testosterone hormone compared with +ve control positive group, while treated experimental groups had significant increase of testosterone values as compared to +ve control positive group. The highest increase in testosterone value was recorded at the group fed on $10 \%$ watercress.

Jamshid, et al., (2017) reported that the mean of fast mobility increased significantly in groups treated with hydroalcohoic extract of watercress. Whereas, the rate of FSH, LH and testosterone significantly increased. Thus, hydroalcohoic extract of watercress could be improving the reproductive parameters and significantly increased sex hormones. This favorable impact suggests that the consumption of watercress may enhance fertility. These results were in agreement with the obtained results. Moreover, Aitken and Roman, (2008), and Glade and Smith, (2015), showed that the number of abnormal sperms decreased in groups treated with watercress. In addition, the administration of watercress hydroalcoholic extract partially increased sperm indexes.

Gurel et al., (2005) reported that vitamin E is a potent hydrophobe antioxidant which is essential for keeping of spermatogenesis in mammals. Vitamin $\mathrm{E}$ increases the living capability of sperm by boosting the antioxidant system. The decrease of vitamin $\mathrm{E}$ results in oxidative stress of testicular tissue and therefore reduces 
synthesis of testosterone and spermatogenesis. Vitamin E has the ability to rebuild seminiferous tubules after damages induced by ozone gas, reduce its damaging effects on testicular tissue and enhancing blood testicular-barrier Aitken and Roman, (2008), The Vitamins and mineral constituent of watercress according to different sources were vitamin A $420 \mu \mathrm{g}$, vitamin E $1.5 \mathrm{mg}$, vitamin B1 0.16 $\mathrm{mg}$, zinc $0.75 \mathrm{mg}$ and selenium $2 \mu \mathrm{g}$ ) per $100 \mathrm{~g}$ (Food Standards Agency, 2002 and Pradhan et al., 2015).

Vitamin E appears to be associated with positive reproductive outcomes. It has been recognized that vitamin $\mathrm{E}$ is a potent hydrophobe antioxidant that is essential for spermatogenesis in mammals (Fatemehet al., 2017) and reacts with free radicals and protects membranes and proteins against oxidative stress damage (Mohasseb et al., 2011).

Vitamin $\mathrm{E}$ analysis in green vegetables is performed by an array of different methods. Method sensitivity was established (below $0.02 \mu \mathrm{g} / \mathrm{g}$ fresh weight), vitamin E $1.5 \mathrm{mg}$ and accuracy was assessed by recovery tests ( $>96 \%)$ (Rebeca and Susana, 2013).

Table (2): Effect of reused oil and watercress on serum FSH, LH and testosterone of male rats.

\begin{tabular}{|l|c|c|c|}
\hline Groups Parameters & $\begin{array}{c}\text { FSH } \\
(\mathbf{m I U} / \mathbf{m l})\end{array}$ & $\begin{array}{c}\text { LH } \\
(\mathbf{I U} / \mathbf{L})\end{array}$ & $\begin{array}{c}\text { Testosterone } \\
(\mathbf{n g} / \mathbf{m l})\end{array}$ \\
\hline G1:Control (-ve) & $0.08 \pm 0.023^{\mathrm{a}}$ & $0.30 \pm 0.058^{\mathrm{ab}}$ & $572.50 \pm 9.54^{\mathrm{b}}$ \\
\hline G2:Control (+ve) & $0.06 \pm 0.007^{\mathrm{a}}$ & $0.16 \pm 0.023^{\mathrm{b}}$ & $137.00 \pm 8.02^{\mathrm{e}}$ \\
\hline G3:Watercress 5\% & $0.08 \pm 0.048^{\mathrm{a}}$ & $0.30 \pm 0.058^{\mathrm{ab}}$ & $365.10 \pm 2.49^{\mathrm{d}}$ \\
\hline G4:Watercress7.5\% & $0.06 \pm 0.035^{\mathrm{a}}$ & $0.36 \pm 0.030^{\mathrm{a}}$ & $452.90 \pm 3.55^{\mathrm{c}}$ \\
\hline G5:Watercress 10\% & $0.13 \pm 0.30^{\mathrm{a}}$ & $0.38 \pm 0.044^{\mathrm{a}}$ & $1233.83 \pm 10.9^{\mathrm{a}}$ \\
\hline
\end{tabular}

Egyptian Journal for Specialized Studies - Vol (8) N (25) January 2020( 13 ) 
Results are expressed as mean \pm SE.

Values in each column which have different letters are significantly different at $(\mathrm{P}<0.05)$.

Table (3) illustrates the effect of reused oil and watercress supplementation on serum MDA and CAT of male albino rats. The mean values of the MDA of - ve control negative group and +ve control positive group were $78.21 \pm 4.87$ and $149.83 \pm 4.88 \mathrm{nmol} / \mathrm{ml}$. This means that $+\mathrm{ve}$ control positive group had significant $(\mathrm{P}<0.05)$ increase of MDA compared with -ve control negative group. While, all experimental treated groups had significant $(\mathrm{P}<0.05)$ decrease of the mean value of MDA, compared to the $+v e$ control positive group.

Moreover, the there was no significant differences of MDA value between the group fed $10 \%$ watercress and the -ve control negative group.

Regarding to the mean value of catalase, the $+\mathrm{ve}$ control positive group and -ve control negative group were $129.45 \pm 4.23$ and $68.83 \pm 2.91 \mu / \mathrm{L}$, respectively. This means that $-\mathrm{ve}$ control negative group was significantly higher compared with +ve control positive group. The values of al treated groups were significantly $(\mathrm{P}<0.05)$ higher compared with the +ve control positive group.

Free radicals generated during the frying process could damage membrane lipids through lipid peroxidation, subsequently leading to oxidative stress. The phenolic, polyphenols and flavonoids content, as well as the radical scavenging activity confirms the high antioxidant capacity and thus, protective effect against oxidative stress of watercress extracts (Zeb, 2015, and Fenton et al., 2018). 
Shahrokhi et al., 2009 mentioned that the watercress is important source of vitamins and a good detoxifying herb. Its high content of vitamin $\mathrm{C}$ and minerals makes it a remedy that is particularly significant for chronic illness. The Vitamins and mineral constituent of watercress according to different sources were vitamin A $420 \mu \mathrm{g}$, vitamin E $1.5 \mathrm{mg}$, vitamin B1 $0.16 \mathrm{mg}$, zinc $0.75 \mathrm{mg}$ and selenium $2 \mu \mathrm{g}$ ) per 100g (Food Standards Agency, 2002 and Pradhan et al., 2015).

Alam, (2015) identified fourteen phenolic compounds in the leaves of watercress, where coumaric acid and its derivatives, caftaric acid and quercetin derivatives were present in huge amounts. Bahramikia and Yazdnaparast (2010) reported that the watercress extract contain the phenolic and flavonoid contents of $96.2 \mathrm{mg}$ gallic acid equivalents/g dried extract and $63.2 \mathrm{mg}$ catechin equivalents/ $g$ dried extract, respectively. The extract possessed potent antioxidant properties which mediated through direct trapping of free radicals, reducing power and as well as through metal chelating.

Heim et al., (2002) and Jamalan et al., (2016), reported that flavonoids arise from the potential health benefits attributed to the antioxidant activities of these polyphenolic compounds. Functional hydroxyl groups in flavonoids mediate their antioxidant effects by scavenging free radicals and/ or by chelating metal ions.

During the heating process, reactive oxygen species, such as hydroperoxides, are produced (Udilova et al., 2003) and cause oxidative stress-induced cytotoxicity (Srivastava 
et al., 2010 and Rouaki at al., 2013). The MDA is one of the end products of lipid peroxidation that is considered as an index for cell damage (Ayala et al., 2014). Oxidative stress is proposed as a stimulatory factor in increasing inflammatory mediators (Munoz and Costa, 2013).

This kind of hepatic inflammation was also observed in previous studies by repeatedly heated soy oil (Jaarin et al., 2010).Prolonged heating induces chemical reactions in oil, such as oxidation, hydrolysis, and polymerization (Zhang et al., 2012) which produce oxidized fatty acids, polar compounds, polymers, hydroperoxides, and aldehydes and upon consumption could cause serious health consequences in fried food consumers (Dobarganes and Marquez, 2015). The presence of rutin in watercress extracts can neutralize free radicals and inhibit lipoperoxidation, which in turn prevents oxidative stress ultimately providing cytoprotection. Also, these compounds significantly decrease ROS and increase endogenous antioxidant enzymes (Oyenihi et al., 2014).

Table (3): Effect of reused oil and different watercress levels on serum MDA and CAT of male rats.

\begin{tabular}{|l|c|c|}
\hline \multicolumn{1}{|c|}{ Parameters } & $\begin{array}{c}\text { MDA } \\
(\mathbf{n m o l} / \mathbf{m l})\end{array}$ & $\begin{array}{c}\text { CAT } \\
(\boldsymbol{\mu} / \mathbf{L})\end{array}$ \\
\hline Groups & $78.21 \pm 4.87^{\mathrm{d}}$ & $129.45 \pm 4.23^{\mathrm{a}}$ \\
\hline G2:Control (-ve) & $149.83 \pm 4.88^{\mathrm{a}}$ & $68.83 \pm 2.91^{\mathrm{e}}$ \\
\hline G3:Watercress 5\% & $123.78 \pm 1.45^{\mathrm{b}}$ & $81.78 \pm 3.30^{\mathrm{d}}$ \\
\hline G4:Watercress7.5\% & $96.06 \pm 5.61^{\mathrm{c}}$ & $92.83 \pm 2.63^{\mathrm{c}}$ \\
\hline G5:Watercress 10\% & $82.16 \pm 3.15^{\mathrm{d}}$ & $111.00 \pm 4.00^{\mathrm{b}}$ \\
\hline
\end{tabular}

Mean values are expressed as means \pm SE.

Means with different superscript letters in the column are significantly different at $\mathrm{P}$ $<0.05$ 
Table (4) illustrates the effect of reused oil and watercress on AST, ALT and ALP of male rats. The +ve group positive had significant $(\mathrm{P}<0.05)$ decrease of liver functions, compared to the -ve control negative group.

There was no significant changes of liver functions (ALT and ALP) between the group fed on 5\% watercress and the +ve control positive group, however the three groups in AST were significant compared to the positive $(+v e)$ control positive group. On the other hand, supplementation with watercress at the level of 7.5 and $10 \%$ caused a significant $(\mathrm{P}<0.05)$ increase in the values of liver functions, compared to the +ve control positive group.

Natanzi et al., (2010) showed that N. officinale may play a protective role against acetaminophen-induced hepatotoxicity through maintaining the normal liver functions.

Table (4) Effect of reused oil and different watercress levels on serum liver functions of male rats

\begin{tabular}{|l|c|c|c|}
\hline Groups Parameters & $\begin{array}{c}\text { AST } \\
(\boldsymbol{\mu} / \mathbf{L})\end{array}$ & $\begin{array}{c}\text { ALT } \\
(\boldsymbol{\mu} / \mathbf{L})\end{array}$ & $\begin{array}{c}\text { ALP } \\
(\boldsymbol{\mu} / \mathbf{L})\end{array}$ \\
\hline G1:Control (-ve) & $158.15 \pm 4.18^{\mathrm{a}}$ & $61.83 \pm 1.62^{\mathrm{a}}$ & $374.90 \pm 3.03^{\mathrm{a}}$ \\
\hline G2:Control (+ve) & $112.28 \pm 2.70^{\mathrm{d}}$ & $34.33 \pm 2.56^{\mathrm{c}}$ & $259.30 \pm 3.95^{\mathrm{c}}$ \\
\hline G3:Watercress 5\% & $123.16 \pm 2.32^{\mathrm{c}}$ & $39.61 \pm 1.55^{\mathrm{c}}$ & $268.45 \pm 1.87^{\mathrm{c}}$ \\
\hline G4:Watercress7.5\% & $126.38 \pm 2.23^{\mathrm{c}}$ & $50.61 \pm 3.08^{\mathrm{b}}$ & $351.40 \pm 9.08^{\mathrm{b}}$ \\
\hline G5:Watercress 10\% & $138.45 \pm 5.27^{\mathrm{b}}$ & $54.50 \pm 3.90^{\mathrm{ab}}$ & $357.43 \pm 4.98^{\mathrm{b}}$ \\
\hline
\end{tabular}

Results are expressed as means $\pm \mathrm{SE}$.

Means with different superscript letters in the column are significantly different at $\mathrm{P}$ $<0.05$

Table (5) showed the effect of reused oil and watercress on mean values of TC, TG, HDL-c, LDL-c and VLDL-c of male albino rats. The + ve control positive 
group had significant increase of the values of lipid profile compared to the $-\mathrm{ve}$ control negative group. The supplementation with the three different levels of watercress caused a significant decrease $(\mathrm{P}<0.05)$ of the mean value of TC, TG, LDL-c and VLDL-c and significant increase $(\mathrm{P}<0.05)$ of HDL-c compared to the +ve control positive group.

In deep fat frying, often the fat is kept hot for a long period of time at $180^{\circ} \mathrm{C}$ and moisture and air are mixed into the hot oil. The fried food absorbs this heated oil. The oxidation of oil produces oxygen-derived free radicals and hydroxylated products that are harmful to tissues of the body (Frankel, 1980) producing adverse effect like hemolytic anemia, increased blood clotting time and hepatomegaly (Isong et al., 1992). Reproductive toxicity, elevation of TC and free fatty acid levels of various tissues, thrombocytopenia and enhanced platelet aggregation levels have also been documented (Owu et al., 1998).

Prasad et al., (2016) reported that, free radicals play a major role in development and progression of atherogenesis. Oxidized LDL is considered as one of the most important factor in the development of atherogenesis. The free radicals oxidize normal LDL to oxidized LDL, which is taken up by macrophages. Excessive uptake of modified macrophages causes the transformation of these cells into foam cells, which participates in formation of atherosclerotic plaques (Ferrier, 2015). Susceptibility of LDL to oxidation depends both on concentration of prooxidant stimuli and the entity and concentration of antioxidants (Dobreanu and Módy, 1997). 
Consistent with the results of the current study, (Kamsiah et al., 2001) showed that after 20 weeks of consumption of 5 times-heated palm oil, LDL-c levels increased, yet no significant change in HDL-c levels was observed. In this context, (Garrido Polonio et al., 2004 and Ghobadi et al., 2017) showed negative alterations in lipid profile of rats fed heated sunflower oil may be due to decreased intake of unsaturated fatty acids, especially linoleic acid. Changes in lipid profile following consumption of heated oil could increase atherosclerosis risk as indicated by (Adam et al., 2008).

Table (5): Effect of reused oil and different watercress levels on serum lipid profile of male rats

\begin{tabular}{|l|c|c|c|c|c|}
\hline \multirow{2}{*}{ Groups Parameters } & TC & TG & HDL-c & LDL-c & VLDL-c \\
\cline { 2 - 7 } & \multicolumn{5}{|c|}{ (mg/dl) } \\
\hline G1:Control (-ve) & $67.35 \pm 2.85^{\mathrm{bc}} \mathrm{c}$ & $50.01 \pm 3.15^{\mathrm{c}}$ & $44.90 \pm 1.43^{\mathrm{a}}$ & $12.44 \pm 2.79^{\mathrm{cd}}$ & $10.00 \pm 0.63^{\mathrm{c}}$ \\
\hline G2:Control (+ve) & $86.86 \pm 2.12^{\mathrm{a}}$ & $69.50 \pm 2.77^{\mathrm{a}} \mathrm{a}$ & $24.18 \pm 0.77^{\mathrm{c}}$ & $48.78 \pm 1.86^{\mathrm{a}}$ & $13.90 \pm 0.55^{\mathrm{a}}$ \\
\hline G3:Watercress 5\% & $73.36 \pm 2.57^{\mathrm{b}}$ & $58.36 \pm 1.98^{\mathrm{b}}$ & $34.95 \pm 1.31^{\mathrm{b}}$ & $26.74 \pm 3.00^{\mathrm{b}}$ & $11.67 \pm 0.39^{\mathrm{b}}$ \\
\hline G4:Watercress7.5\% & $70.10 \pm 2.81^{\mathrm{bc}} \mathrm{c}$ & $46.28 \pm 1.73^{\mathrm{c}}$ & $41.05 \pm 1.70^{\mathrm{a}}$ & $19.79 \pm 2.86^{\mathrm{bc}}$ & $9.25 \pm 0.34^{\mathrm{c}}$ \\
\hline G5:Watercress 10\% & $63.75 \pm 2.73^{\mathrm{c}}$ & $48.45 \pm 3.57^{\mathrm{c}}$ & $43.00 \pm 1.75 \mathrm{a}$ & $11.06 \pm 1.91^{\mathrm{d}}$ & $9.69 \pm 0.71^{\mathrm{c}}$ \\
\hline
\end{tabular}

Mean values are expressed as means $\pm \mathrm{SE}$.

Means with different superscript letters in the column are significantly different at $\mathrm{P}$ $<0.05$.

Table (6) illustrates the effect of reused oil and different watercress levels on semen quality of adult male rats. The count of normal semen were significantly decreased and total abnormal semen of were significantly increased at the +ve control group as compared to the -ve control group. All treated groups had significant increase $(\mathrm{P}<0.05)$ of the number of Normal semen. While the total

Egyptian Journal for Specialized Studies - Vol (8) N (25) January 2020( 19 ) 
abnormal semen was significantly $(\mathrm{P}<0.05)$ decreased, compared to positive control group.

Atrophy of seminiferous tubules and reduction of spermatogenic cells are morphological signs of spermatogenesis disorders. It has been recognized that vitamin $\mathrm{E}$ is a potent biological antioxidant that is completely essential for the maintenance of spermatogenesis in mammals, vitamin E $1.5 \mathrm{mg}$ in watercress (Cao et al., 2004).

In normal condition, there are antioxidant agents in genital tissues and inhibit the appearance damage oxidative in gonad cell and adult spermatozoa (Aprioku, 2013). Researchers have demonstrated that vitamins E, C and B have been effective in reducing the toxic effects of cadmium on testicular tissues and the process of spermatogenesis (AlAttar, 2011). Antioxidant functions of watercress have been proved due to existence of vitamin $\mathrm{C}$ in it. Existence of these elements in watercress may have affected the partial improvement on indexes of sperm Jamshid, et al., (2017), vitamin A $420 \mu \mathrm{g}$, vitamin E $1.5 \mathrm{mg}$, vitamin B1 $0.16 \mathrm{mg}$, zinc $0.75 \mathrm{mg}$ and selenium $2 \mu \mathrm{g}$ ) per $100 \mathrm{~g}$ in watercress (Food Standards Agency, 2002 and Pradhan et al., 2015).

Results of this study demonstrated the sperm index's effects of antioxidant feature of watercress on the improvement of sperm indexes. Moreover, the existence of flavonoids and some other antioxidants such as: vitamin $\mathrm{E}$ (Leth and Sondergaro, 1983), vitamin A (Vita, 1996), $B_{1}$ and $\mathrm{B}_{2}$ (Danishofflcial, 1996), and total flavonoids (Arvouet et al., 1994) in watercress are able to improve sperm indexes near to normal. 
At conclusion: As indicated from this study it could be recommended that Watercress is considered as functional food which improves male fertility, while the used oil has negative effects on human health in general and reproductive health in particular.

Table (6): Effect of reused oil and different watercress levels on semen quality of male rats

\begin{tabular}{|c|c|c|c|c|c|c|c|c|c|}
\hline \multirow{2}{*}{$\begin{array}{l}\text { Parameters } \\
\text { Groups }\end{array}$} & Normal & $\begin{array}{l}\text { Small } \\
\text { Heal }\end{array}$ & $\begin{array}{l}\text { Big } \\
\text { Head }\end{array}$ & Hookless & Banana & $\begin{array}{l}\text { Abnormal } \\
\text { Tail }\end{array}$ & Amorphous & Total abnormal & Testes \\
\hline & \multicolumn{9}{|c|}{$\%$} \\
\hline Control (-ve) & $79.0 \pm 2.26^{2}$ & $0.00 \pm 0.00^{2}$ & $0.33 \pm 0.33^{2}$ & $1.83 \pm 0.40^{b}$ & $8.83 \pm 1.01^{\mathrm{ab}}$ & $5.00 \pm 1.61^{b}$ & $5.00=1.03 \mathrm{c}$ & $21.00 \pm 2.26^{\circ}$ & $2.32 \pm 0.22^{2}$ \\
\hline Control (+ve) & $58.66 \pm 2.37^{\circ}$ & $0.00 \pm 0.00^{2}$ & $0.50 \pm 0.22^{\mathrm{a}}$ & $5.83 \pm 0.98^{\mathrm{a}}$ & $1233 \pm 125^{\mathrm{a}}$ & $8.0 \pm 0.81^{\mathrm{bb}}$ & $14.66 \pm 190^{2}$ & $41.33 \pm 237^{\mathrm{a}}$ & $1.51 \pm 0.0]^{-6}$ \\
\hline Watercress 5\% & $73.66 \pm 1.25$ ib & $0.16 \pm 0.16^{2}$ & $0.00 \pm 0.00^{2}$ & $1.83 \pm 0.79^{6}$ & $11.50 \pm 1.38^{83}$ & $4.0 \pm 0.68^{6}$ & $8.83+0.94^{6 x}$ & $26.33 \pm 1.25_{\mathrm{wa}}^{\mathrm{be}}$ & $1.63 \pm 0.20^{b}$ \\
\hline Watercress $7.5 \%$ & $67.50 \pm 4.52^{b}$ & $0.00 \pm 0.00^{2}$ & $0.00 \pm 0.00^{2}$ & $2.50 \pm 1.32^{b}$ & $8.83 \pm 1.0^{\text {ab }}$ & $12.16 \pm 3.78^{2}$ & $8.66 \pm 0.95 \mathrm{bx}$ & $32.50 \pm 4.52^{b}$ & $1.26 \pm 0.03^{36}$ \\
\hline Watercress 10\% & $6933 \pm 2.02^{\mathrm{b}}$ & $0.00 \pm 0.00^{2}$ & $0.00 \pm 0.00^{2}$ & $1.00 \pm 0.25^{b}$ & $7.83=1.24^{b}$ & $10.00 \pm 1.31^{1 b}$ & $11.83 \pm 2.10^{20}$ & $30.66 \pm 2.02^{b}$ & $1.31 \pm 0.06^{6}$ \\
\hline
\end{tabular}

Mean values are expressed as means $\pm \mathrm{SE}$.

Means with different superscript letters in the column are significantly different at $\mathrm{P}$ $<0.05$.

\section{Reference:}

- Abdullah, Ç.; Erman D.and Mehmet M. (2012): Effects on Edibility of Reused Frying Oils in the Catering Industry. Journal International Journal of Food Properties , 15(1):69-80.

- Adam, SK.; Das S, Soelaiman, IN.; Umar NA.andJaarin K.(2008): Consumption of repeatedly heated soy oil increases the serum parameters related to atherosclerosis in ovariectomized rats. Tohoku J Exp Med; 215(3):219-26.

- Aebi, H. (1984):MethodsEnzymol 105, 121-126.

- Agarwal, A.;Makker, K. and Sharma R. (2008): Clinical relevance of oxidative stress in male factor infertility: an update. Am J ReprodImmunol; 59: 2-11

Egyptian Journal for Specialized Studies - Vol (8) N (25) January 2020( 21 ) 
- Agarwal, A.;Virk, G.;Ong, C. and Du Plessis, S.S. (2014): Effect of oxidative stress on male reproduction.World J. Men's Health; 32:1-17.

- Aitken, RJ. and Roman, SD. (2008): Antioxidant systems and oxidative stress in the testes. Oxid Med Cell Longev; 1: 15-24.

- Alam, Z., (2015): Phenolic profile and antioxidant potential of wild watercress (N. officinale L.). Zeb Springer Plus. 4:714.

- Al-Attar A.M. (2011): Antioxidant effect of vitamin E treatment on some heavy metals-induced renal and testicular injuries in male mice. Saudi J BiolSci; 18:63-72.

- Aprioku, JS. (2013): Pharmacology of Free Radicals and the Impact of Reactive Oxygen Species on the Testis. J ReprodInfertil; 14: 158-172.

- Arvouet-Grand, A.,Vennat, B., Pourrat, A. and Legret, P.,(1994): Standadisation d, un extrait de propolis et identification des principauxconstituants. Journal de Pharmacic de Belgique 49, 462-468.

- Ayala, A.; Munoz, MF.and Arguelles S. (2014): Lipid peroxidation, production, metabolism, and signaling mechanisms of malondialdehyde and 4 hydroxy 2 nonenal. Oxid Med Cell Longev:360438.

- Azantee, Y.A.W. and Lokman, M.I.(2015): The future of Azoospermic Patients: In vitro spermatogenesis. Andrology; 4:1000143.

- Bahramikia, S. and Yazdanparast, R. (2010): Antioxidant efficacy of Nasturtium officinale extracts using various in vitro assay systems. Journal of Acupuncture and Meridian Studies. 3:283-90.

- Biddington, NL. and Ling, B. (1983): The germination of watercress (Rorippanasturitum-aquaticum) seeds. I. The effects of age, storage, temperature, light and hormones on germination. J HortSci; 58: 417-426.

- Cao, L.; Leers-Sucheta, S. and Azhar S. (2004): Aging alters the functional expression of enzymatic and non-enzymatic antioxidant defense systems in testicular rat Leydig cells. J Steroid BiochemMolBiol; 88: 61-7. 
- Choe, E.and Min. DB. (2007): Chemistry of deep-fat frying oils. J Food Sci. 72: R77-86.

- Collins, W.P., Branch, C, M., Collins, P, O., and Sallam, H, N., (1981): Biochemical indices of the Fertile Period in Women.int.J. Fertil, 26: 196.

- Danishofflcial, (1996): Hplc method No. AB 189.2National Food Agency of Denmark, vitamin C.

- De, Vane.; G.W.; Czckala, N.; M.; Judd, H.L.; and Yen, S.S.(1975): Circulating Gonadotropins,Estrogens, and Androgens in Polycytic Ovarian Disease, Am. J.Obstel. Gynecol. 121: 4969.

- Dobarganes, C. and Marquez G. (2015): Possible adverse effects of frying with vgetable oils. Br Nitr; 113(2):49-57.

- Dobreanu, M. and Módy E. (1997): Influence of natural antioxidants on in-vitro lipoprotein peroxidation. Rom J Intern Med; 35(1-4): 55-62.

- Fatemeh.M.;Ghobadi S.; Masoumeh.A. and Maral.M: The Effects of Heated Oils Used in Fast Food Restaurantson Metabolic, Inflammatory and Oxidative Stress Markers, Blood Pressure, and Liver Histologyin Sprague-Dawley Rats, Corresponding author: Masoumeh Akhlaghi,Ph.D.,Assistant Professorof Nutrition, Nutrition Research Center, School of Nutrition and Food Sciences, Shiraz University of Medical Sciences, RaziBlvd, Shiraz, IRIran., doi: 10.5812/ircmj.59696.

- Fenton, N. MV.; UrquizaMartínez, BB.; Fiscal Castro, OI.; Medrano Castillo, $\mathrm{M}$.;LópezRodríguez, $\mathrm{S}$.; Padilla Arellanes, A. andVázquezHernández. (2018):Afr, J. andTradit Complement Altern Med., 15 (2): 68-79.

- Ferrier, DR. (2015): Lippincott's illustrated Biochemistry, 6th edition. Wolters Kluwer, Lippincott William \& Wilkins Publishers, New Delhi; 231-234.

- Food Standards Agency, (2002):McCance\&Widdowson's The Composition of Foods, 6th Summary Edition. Cambridge: Royal Society of Chemistry. 
- Fossati, P., and Prencipe, L.(1982): $\quad$ Triglycerides determination after enzymatic hydrolysis.Clin.Chem.,28:2077.

- Frankel. E. (1980): Lipid oxidation: Mechanisms, products and biological significance. Journal of the American Oil Chemists' Society. 61 (12): 1908-1917.

- Friadwald, W.; Levy, K. and fredrickson, D.(1972): Estimation of the concentration of low density lipoprotine cholesterol in plasma without use of the preparative ultracentrifuge. Clin. Chem.226:499-504.

- Fujii,J. and Imai, H. (2014): Red oxreactions in mammalian spermatogenesis and the potentialtargets of reactive oxygen species under oxidative stress. Spermatogenesis; 4: e979108.

- Garrido P. C.; Garcia Linares, MC.; Garcia Arias, MT.; Lopez Varela, S.; Garcia Fernandez, MC.; Terpstra AH. and et al.(2004): Thermally oxidised sunflower seed oil increases liver and serum peroxidation and modifies lipoprotein compositioninrats.BrJNutr;92(2):257-65.

- Gill, CI.;Haldar, S.; Boyd, LA.; Bennett, R.;Whiteford, J. and Butler M,.(2007): Watercress supplementation in diet reduces lymphocyte DNA damage and alters blood antioxidant status in healthy adults. Am J Clin Nutr; 85:504-10.

- Glade, MJ.and Smith K. (2015): Oxidative Stress, Nutritional Antioxidants, and Testosterone Secretion in Men. Ann NutrDisord\&Ther; 2: 121.

- Goda, Y.; Hoshino, K.; Akiyama, H.; Ishikawa, T.; Abe, Y. and Nakamura, T. (1999): Constituents in Watercress: inhibitors of histamine release from RBL-2H3 cells induced by antigen stimulation. Biol Pharm Bull; 22: 1319-26.

- Gurel, A.;Coskun, O.;Armutcu, F.;Kanter, M. and Ozen OA. (2005): Vitamin E against oxidative damage caused by formaldehyde in frontal cortex and hippocampus: biochemical and histological studies. J ChemNeuroanat; 29: 173-8.

- Haesslein, H,C, and Lamb, E,H. (1976): Pituitary Tumors in patients with SecondryAmenorrhea.Am. J. Obstel, Gynecol, 125: 759 . 
- Heim, KE.;Tagliaferro, AR. and Bobilya, DJ.(2002): Flavonoid antioxidants: chemistry, metabolism and structureactivity relationships. J NutrBiochem; 13(10): 572-584.

- Isong, EU.;Ifon, ET.;Eka, EU.;Essien, EU.andUmoh IB.( 1992): Effect of intermittently thermoxidized palm oil on normal and malnourished rats. Trop J ApplSci, 2:118-121.

- Jaarin, K.;Hwa, TC.; Umar, NA.;SitiAishah, MA. and Das S.(2010): Enzymatic and microstructural changes in the liver of experimental rats fed with fatty dietandfreshor heated soy oil concurrently.ClinTer;161(5):429-33.

- Jafari, S. and Hassandokht, M. (2012): Evaluation of some Iranian watercress (Nasturtium officinale L.) populations using agro-morphological traits. Int J Forest, Soil and Erosion; 2:119123.

- Jamalan, M.;Ghaffari, MA.;Hoseinzadeh, P.;Hashemitabar, M. and Zeinali M.(2016): Human sperm quality and metal toxicants: protective effects of some flavonoids on male reproductive function. Int J FertilSteril; 9(3): 215-222.

- Jamshid, M.;Farideh, T.M.;Nasrin, M.(2017): The Effect of Hydroalcoholic Extract of Watercress on Parameters of Reproductive and Sex Hormones on the Diabetic Rats. 9(8), 1334-1338.

- Kamsiah, J.; Aziz, SN.;Siew, ST.andZahir IS.( 2001): Changes in serum lipid profile and malondialdehyde following consumption of freshorheatedredpalmoil.MedJIslamAcadSci; 14: 79-86.

- Kaviyani, M.; Ghazi, NM.;Shariati, MA. andAtarod S.( 2014): The study of frying oils properties. Int J AdvEng Res Tech; 2: 90-96.

- Khalil,F.F.; Mehrim,A.I. and Refaey,M.M.(2015): " Impact of Dietary Rocket (Eruca sativa) Leaves or Seeds on Growth Performance, Feed Utilization, Biochemical and Physiological Responses of Oreochromisniloticus, Fingerlings . ",Asian Journal of Animal Sciences 9 (4): 134147.

Egyptian Journal for Specialized Studies - Vol (8) N (25) January 2020( 25 ) 
- Leong, XF.; Ng, CY.;Jaarin. K. and Mustafa MR. (2015): Effects of Repeated Heating of Cooking Oils on Antioxidant Content and Endothelial Function. Austin J PharmacolTher; 3(2). 1068 .

- Leth, T; and H. Sondergaro. (1983): Biological activity of allrac-tocopherol determined by three different rat bioassays int.J, Vit, Nutr. Res. 53,297-311.

- Mohasseb, M.;Ebied, S.;Yehia, M A H. and Hussein N, (2011): Testicular oxidative damage and role of combined antioxidant supplementation in experimental diabetic rats. Journal of Physiology and Biochemistry 67: 185-194.

- Munoz, A. and Costa M.(2013): Nutritionally mediated oxidative stress and inflammation. Oxid Med Cell Longev:1-11.

- Natanzi A.R.; Ghahremani M.H.; H.R. Esfehani M.; Minaei M.B.; Nazarian H. and Sabzevari O. (2010): Evaluation of Antihepatotoxic Effect of Watercress Extract and its Fractions in Rats. International Journal of Pharmacology. Volume 6 (6): 896-902.

- Owu, DU.;Osim, EE.andEbong PE. (1998): Serum liver enzymes profile of Wistar rats following chronic consumption of fresh or oxidized palm oil diets. ActaTropica, 69:65-73.

- Oyenihi, A.B.; Brooks, N.L.;Oguntibeju, O.O. andAboua, G. (2014): Antioxidant- Rich Natural Products and Diabetes Mellitus. In: Antioxidant- Antidiabetic Agents and Human Health. Intech.Chapter 14.Pp: 317-345

- Park S.;Dong Youp.; Shin Do.; Rim K .;Woong M Y.;Mun S C. and Seong K. P,(2007): Korean ginseng induces spermatogenesis in rats through the activation coofcAMP responsive element modulator (CREM), Fertil Steril;88:1000-2.

- Pradhan.S.;S. Manivannan. and J. P. Tamang. (2015): Proximate, mineral composition and anti-oxidant properties of some wild leafy vegetables. Journal of Scientific and Industrial Research. 74: 155-159.

- Prasad, RM.;Urban D.; Shankar, B. and Kumar, M. (2016): Effect of vegetable oils on the lipid profile and antioxidant 
status in Wistar rats: A comparative study, Journal of International Medicine and Dentistry; 3(2): 109-114.

- Rebeca, C. andSusana, C. (2013): Validation of a fast and accurate chromatographic method for detailed quantification of vitamin E in green leafy vegetables,141(2) 15: 1175-1180.

- Reeves, P.;Nielesen, F. and Fahey, G. (1993): AIN-93 purified diets for laboratory rodents: final report of the American Institute of Nutrition ad hoc writing committee on the reformulation of the AIN-76A rodent diet. J Nutr; 123:19391951.

- Rouaki, F.;Mazari, A.;Kanane, A.;Errahmani, MB and Ammouche A. (2013): Cardiotoxicity induced by dietary oxidized sunflower oil in rats, pro and antioxidant effect of alpha tocopherol. Int J Vitam Nutr Res; 83(6):367-76.

- Satoh,K., (1978):ClinicaActa ,90,37.

- Shahrokhi, N.; M. K. Hadad, Z.;Keshavarzi, and M. Shabani. (2009): Effect of aqueous extract of watercress on glucose and lipid plasma in streptozotocin induced diabetic rats. Pakistan Journal of Physiology. 5(2): 610.

- Shih, W.J;Bachorik, P.S;Haga, J.A; Myers, G.L. and Stein E.A.(2000): Clinical Chemistry, 46:3:351-364.

- SPSS, (1986): Statistical package for social science, version 18. SPSS Inc., II. U.S.A.

- Srivastava, S.; Singh, M.; George, J.;Bhui, K.;Murari Saxena, A. and Shukla Y. (2010): Genotoxic and carcinogenic risks associated with the dietary consumption of repeatedly heated coconut oil. Br J Nutr; 104(9):1343-52.

- Thomas,L. (1998): Alanine aminotransferase (ALT), aspartate amino transeferase (AST).Clinical Laboratory Diagnostic . $1^{\text {st }}$ ed. Frankfurt: TH-Books Verlagsgesellschaft.p.55-65.

- Udilova, N.;Jurek,D.;Marian, B.;Gille, L.; Schulte Hermann, R. and Nohl H.(2003): Induction of lipid peroxidation in bio membranes by dietary oil components. Food ChemToxicol; 41 (11):1481-9. 
- Vita. (1996): Danish official, Hplcnethod No, AF 255.1,3 REDED, National food Agency of Denmark.

- Young, DS. (2000): Effects of Drugs on Clinical Laboratory Tests, Fifth Edition, AACC Press, Washington, D, C, 3-8-3-23.

- Zeb, A. (2015): Phenolic profile and antioxidant potential of wild watercress (Nasturtium officinale L) ZebSpringerPlus. $4: 714$.

- Zhang, Q.;Saleh, AS.; Chen, J. and Shen Q. (2012): Chemical alterations taken place during deep-fat frying based on certain reaction products: a review. ChemPhys Lipids; 165: 662-681. 